\title{
Negative life events, coping and mental health in middle childhood
}

\section{BACKGROUND}

In the period of middle childhood, social experiences (both educational and social) may constitute a critical moment in time for the ultimate results of development in the case of an individual. Negative life events and coping skills may guarantee a positive or negative direction of development, exerting an influence on the mental health of children. In the study, a four-factor model of mental health was adopted, taking into consideration psychopathological symptoms within the scope of externalizing and internalizing disorders, the level of the performance of developmental tasks, and the sense of life satisfaction. The present study investigated the correlation between stress, coping and mental health in children in middle childhood.

\section{PARTICIPANTS AND PROCEDURE}

The study included 182 individuals aged between 9 and 12 years. The following aspects were subjected to assessment: the level of mental health, the number and severity of negative life events, and the strategies of coping with stress. In order to determine the strongest predictors of the four dimensions of mental health of children, hierarchical regression analysis was applied.

\section{RESULTS}

It was found that the strongest predictor of mental health of children in the period of middle childhood was individual and accumulated negative stress events. Lower significance was found for the subjective assessment of the severity of events being experienced. It was found that a factor protecting against disorders was active methods of coping.

\section{CONCLUSIONS}

The study suggests that it is not only psychopathological symptoms that constitute the negative consequence of the effect of stress. Negative stress events influence the positive dimensions of mental health, including the level of performance of developmental tasks and the sense of life satisfaction in children in the period of middle childhood. The obtained results show the specific character of the discussed period of development. However, these issues still need to be explored further.

\section{KEY WORDS}

stress; life satisfaction; youth development; externalizing; internalizing problems 


\section{BACKGROUND}

Both theoretical conceptions and empirical research indicate that the experiences of the first years of life constitute the foundations of shaping mental health or the occurrence of disorders during childhood and adulthood, and, even though the role of the first life experiences is incontrovertible, in the period of middle childhood as well there occur social experiences which may constitute a critical moment in time

Iwona for the ultimate results of development (Feinstein Grzegorzewska \& Bynner, 2004). The years spent in school offer a child plenty of experiences, both educational and social, which may support the correct development of a child or constitute a risk factor of the occurrence of disorders. Experiencing stress, and also coping skills, may guarantee the positive or negative direction of development (Robins \& Rutter, 1990; Rolf, Masten, Cicchetti, Nuechterlin, \& Weintraub, 1990).

Very frequently, mental health is defined in medical categories as the lack of certain symptoms of diseases. In scientific literature, and, in particular, in empirical research, attempts to provide a more precise definition of health have been made for several years. Some authors adhere to the opinion that in connection with the subjective character of the notion referred to as "health", developing a complete and exhaustive definition is not possible (Melosik, 1999). Notwithstanding that, the one which is applied most frequently is the definition adopted by the World Health Organization, which determines health not only as the absence of illness or infirmity, but, in a more complete way, as the state of well-being in all the spheres of the functioning of a human being. Health understood in such a way is a positive category. Taking into consideration the current state of knowledge about mental health in general, and making attempts to apply that notion to the course of the development of children and youth, it is necessary to take into consideration the three dimensions of the mental health of youth: 1) clinical, understood as the absence of or a low level of psychopathological symptoms; 2) developmental, treated as the correct level of the performance of developmental tasks, and 3) positive, meaning welfare, understood as the sense of the good quality of life or the sense of life satisfaction (Grzegorzewska, 2013).

As it is estimated in accordance with global statistical data, the phenomenon of the widespread occurrence of mental health disorders in children and youth affects approximately 20\% (WHO, 2005). Currently, there are no exact and precise data estimating that problem in Poland, especially data relevant to the period of middle childhood. Indirectly and from various studies, it is possible to arrive at the conclusion that between $9 \%$ and $30 \%$ of Polish youth suffer from disorders of various kinds (Namysłowska, 2013).
Because the problematic behaviours of children and youth are usually of a dimensional character, and they are situated on a certain continuum, these data are likely to be subject to underestimation. Plenty of youths manifesting social or emotional maladjustment do not fulfil the diagnostic criteria of clinical disorders, and their behaviour results in numerous negative consequences in functioning in the context of school, family and society.

The complexity and severity of mental health disorders make one inclined to consider their determinants. An important factor determining their level is life experiences, which constitute an intermediary link between the subject-related and environmental determinants of the development of a human being. The scope of the life experience of an individual is one of the direct measures of the functioning of that individual in their environment, and the course of their development at an intrapersonal level. Research into the connections between life events and mental health and disorders, as well as the psychological adaptation of children, indicates the significant role not only of any life experience whatsoever, but especially those experiences perceived as negative (Sęk, 1991). The role of positive events experienced by children in the course of their development is not so significant (Grzegorzewska, 2011; Radziwiłłowicz, 2011).

Another important factor exerting a significant influence on the connection between experiencing life stress and physical and mental functioning is the way of coping (Lazarus, 1999). Richard Lazarus and Susan Folkman (1984) emphasize the influence exerted by coping skills in terms of stress on the assessment of subsequent life events being experienced, and on the general functioning of an individual. Coping is defined as the general predisposition of personality which is manifested as the cognitive and behavioural forms of the activity of a human being, the objective of which is to reduce, change or tolerate determined external or internal requirements assessed by an individual human being as burdening them or exceeding the resources at their disposal. Empirical research within the scope of connections between coping strategies and the mental health of children and youth does not provide conclusive answers. According to Liliana Lengua (2002), some styles of coping with stress (for example, an action-oriented style) may help in the development of a child, but some others (for example, avoidance) may intensify difficulties and cause further problems. In other analyses, concentrated on the developmental effects of the various styles of coping with stress, it was found that the approach based on a task is more positively correlated with mental health (for example, there are fewer psychopathological symptoms), whereas avoidance or coping concentrated on emotions is connected with the occurrence of a greater number of disorders (for example, Endler Higgins, 1995). 
In the context of the above considerations, the main research questions of the present study were formulated. Verification of assumptions concerning the role of stress (negative life events) and ability to cope with it in the mental health of an individual was conducted. Such features of mental health as a low level of psychopathological symptoms, a good level of the performance of developmental tasks and a high level of the sense of life satisfaction were subjected to assessment. Answers to the following questions were sought: 1) First, is there an existing connection between the intensity of negative life events and their severity in the subjective assessment by the studied individuals and the selected aspects of mental health? 2) Second, is there an existing connection between the kind of coping strategies applied by children and the level of psychopathological symptoms, the sense of life satisfaction and the performance of developmental tasks? And, ultimately, which of the independent variables being measured are the most significant predictors of mental health disorders in children in the period of middle childhood? Prior to the commencement of the research, the following hypotheses were adopted: 1) negative stress events constitute a risk factor of mental health disorders in children in the period of middle childhood; 2) accumulated risk factors have greater significance than do individual events; 3 ) the higher the level of severity of negative life events in accordance with the assessment by the studied individuals, the greater is the risk of mental health disorders; 4) the dominating strategies in the case of children manifesting a high level of mental health are strategies based on action; 5) strategies based on emotions will constitute a risk factor of mental health disorders; 6) for maintaining mental health, remedial strategies are more significant than experiencing stress and negative life events.

\section{PARTICIPANTS AND PROCEDURE}

\section{STUDIED GROUP}

The research included 182 pupils aged between 9 and 12 years. A total of 92 boys and 86 girls were tested. The age of subjects ranged from 9 to 12 years $(M=10.86, S D=1.20)$. Based on collected socio-demographic data, descriptive statistics were drawn up with reference to the education level of parents and the evaluation of the family's financial situation (see Table 1). The research was conducted individually or on groups in the schools and educational facilities in Zielona Góra. The condition of participating in the study was having obtained the consent of the parents of the children, and of the children themselves.

\section{MEASUREMENT TOOLS}

In the study we applied the three-factor model of mental health (Grzegorzewska, 2013), analysing the following dimensions: the level of psychopathology (exacerbation of symptoms of externalizing and internalizing disorders), the level of performance of developmental tasks, and the sense of life satisfaction. For the assessment of particular variables, the methods enumerated below were applied.

An Assessment of Mental Health: Externalizing and internalizing disorders: the Child Behaviour Checklist (CBCL), the Polish adaptation by Wolańczyk (2002). The data were collected from teachers (Teach-

Table 1

Demographic data: education level of parents and financial status of family

\begin{tabular}{lccc}
\hline & & $n$ & $\%$ \\
\hline \multirow{3}{*}{ Education level of mother } & primary & 17 & 9.30 \\
& vocational & 54 & 29.70 \\
& secondary & 69 & 37.90 \\
& higher & 42 & 23.10 \\
Education level of father & primary & 21 & 11.50 \\
& vocational & 51 & 28.00 \\
Financial status & secondary & 71 & 39.00 \\
& higher & 39 & 21.50 \\
& bad & 43 & 23.60 \\
\hline
\end{tabular}

Correlation of mental health in middle childhood 
ers Report Form - TRF) or parents (CBCL). The items of the $7^{\text {th }}$ and $8^{\text {th }}$ scales were applied to assess externalizing symptoms, and the items of the $1^{\text {st }}, 2^{\text {nd }}$ and $3^{\text {rd }}$ scales were applied to assess internalizing disorders. The response scale ranged from 0 to 2 .

Developmental tasks: Questionnaire for the Attainment of Developmental Tasks (QADT) by Grzegorzewska (2006). The tool consists of three scales which assess the performance of the following basic developmental tasks of school-age children: academic skills, social competence and sense of competence. The QADT has sound psychometric properties, and reliability coefficients obtained for a sample of 120 , range from .77 to .92 (Grzegorzewska, 2006).

Sense of life satisfaction: Brief Multidimensional Students' Life Satisfaction Scale (BMSLSS; Seligson, Huebner, \& Valois, 2003) - the experimental version. The BMSLSS is a five-item self-report measure developed to assess children's satisfaction with respect to the areas of life most pertinent during youth development. Specifically, students are instructed to rate their satisfaction with their family life, friendships, school experiences, self, and then living environment. Response options are on a 7-point scale that ranges from 1 - terrible to 7 - delighted. Coefficient $\alpha$ for the total score (the sum of respondents' ratings across the five items) have been reported at .75 to .81 .

The Assessment of Personal and Environmental Predispositions: Negative Life Events. In the study, the Children and Youth Life Experience Scale was applied (Grzegorzewska, 2006). The scale contains 23 life events having a negative character and situated in areas connected with education in the school context, family life and relationships with peers, and also traumatic, non-normative stress events. The studied individual indicates: 1) whether a given event has occurred in the course of their life; 2) whether it was an individual event, or it has repeated, and also 3) the level of severity of a given event with the application of a five-point scale, on which: 1 means not a very severe experience, whereas 5 means a very severe experience. The scale of life experience makes it possible, therefore, to determine the following indicators: a) the number of negative experiences of events in accordance with subjective assessment of the studied individual; b) the intensity of those experiences; c) their level of severity (Grzegorzewska, 2006).

Coping: For the purpose of the assessment of the ways of coping in difficult situations, the scale "How do you cope?" (HDYC), the authors of which are Zygfryd Juczyński and Nina Ogińska-Bulik (2009), was applied. That method investigates both predispositional, being the manifestation of permanent tendencies in the case of an individual coping in a determined way, as well situational, resulting from the specific character of a difficult situation, ways of coping with stress. Both for situational and predispositional coping, three strategies were differentiated:
1) active coping - an instrumental strategy, oriented on a problem; 2) concentration upon emotions - an emotional strategy consisting in the self-regulation of emotions; 3) searching for social support - a social strategy, particularly important in the case of children and youth. The answers are coded on a four-degree scale, and the results for each strategy may be found in the range from 0 to 12 . A major feature of the scale is its good psychometric properties. Cronbach $\alpha$ reliability coefficients for the predispositional version were between .68 and .73 , whereas for the situational one they are between .66 and .71 . The validity of the scale was investigated using factor analysis and a method correlating the results of HDYC with the results of other scales. Good results were obtained.

\section{RESULTS}

Results are presented in the following two stages: a) correlation analysis and b) hierarchical repeated regression analysis. Due to the lack of normality for the variables being measured, we decided not to provide descriptive statistics, i.e. means and standard deviations.

\section{CORRELATION ANALYSIS}

In the tested model it was assessed whether there are associations between the independent variables and the level of mental health of the studied individuals. The results of the obtained correlations measured with the Pearson $r$-test for the variable of negative life events are provided in Table 2.

The analysis of the results indicates that a high level of mental health of children in the period of middle childhood is positively correlated with the active predispositional and situational strategies of coping with stress, whereas a risk factor is predispositional and situational strategies based on concentration upon emotions. No significant correlations in terms of strategies consisting in searching for support were found.

In relation to the variable of negative life events (compare with Table 3), it was found out that all aspects measured were negatively correlated with mental health. That was applicable both to individual life events and to accumulated ones. Simultaneously, the greater the severity of stress experienced according to the assessment by youth, the lower was the level of their mental health.

\section{REGRESSION ANALYSIS}

In the next step, it was tested which of the studied variables are the strongest predictors of mental 
Table 2

Matrix of the correlation of variables of mental health with the variables of negative life events

\begin{tabular}{|c|c|c|c|c|c|}
\hline & Externalizing & Internalizing & $\begin{array}{c}\text { Psychopathology } \\
\text { in total }\end{array}$ & $\begin{array}{c}\text { Developmental } \\
\text { tasks }\end{array}$ & $\begin{array}{c}\text { Life } \\
\text { satisfaction }\end{array}$ \\
\hline $\begin{array}{l}\text { Individual } \\
\text { negative event }\end{array}$ & .34 & .24 & .40 & -.27 & -.25 \\
\hline $\begin{array}{l}\text { Repeating } \\
\text { negative events }\end{array}$ & .30 & .29 & .40 & -.35 & -.41 \\
\hline $\begin{array}{l}\text { Severity } \\
\text { of negative events }\end{array}$ & .32 & .42 & .50 & -.37 & -.48 \\
\hline
\end{tabular}

Note. All correlations significant at the level of $<.01$.

Table 3

Matrix of variable correlations: mental health with the variables of strategies of coping with stress

\begin{tabular}{|c|c|c|c|c|}
\hline & Externalizing & Internalizing & $\begin{array}{l}\text { Psychopathology } \\
\text { in total }\end{array}$ & $\begin{array}{c}\text { Life } \\
\text { satisfaction }\end{array}$ \\
\hline Predispositional active coping & $-.27^{* *}$ & $-.47^{* *}$ & $-.49^{* *}$ & $.49^{* *}$ \\
\hline $\begin{array}{l}\text { Predispositional concentra- } \\
\text { tion on emotions }\end{array}$ & -.07 & $.28^{* *}$ & .12 & $-.23^{*}$ \\
\hline $\begin{array}{l}\text { Predispositional searching } \\
\text { for support }\end{array}$ & .04 & -.13 & -.05 & .06 \\
\hline Situational active coping & -.20 & $-.40^{* *}$ & $-.40^{* *}$ & $.45^{* *}$ \\
\hline $\begin{array}{l}\text { Situational concentration } \\
\text { on emotions }\end{array}$ & -.04 & $.26^{*}$ & .14 & $-.25^{*}$ \\
\hline $\begin{array}{l}\text { Situational searching } \\
\text { for support }\end{array}$ & .08 & -.19 & -.06 & .07 \\
\hline
\end{tabular}

health of children in the period of middle childhood. The solutions to the regression equation relevant to coping strategies in terms of stress and negative life events indicate an association between them and all the dimensions of mental health of children in the period of middle childhood (see Table 4).

Mental disorders reflecting the mechanism of externalizing problems are explained by the intensity of life stress in the form of individual and accumulated negative life events, as well as the predispositional strategy of coping consisting in concentration upon emotions. It was found that a protective factor was an ability to concentrate upon emotions in a particular difficult situation. Those variables explain $22.20 \%$ of the variance of the intensity of externalizing result.

Mental disorders consisting in internalizing problems are explained by a number of individual negative life events and the low level of predispositional readiness to cope with stress actively. Those two variables explain $23.20 \%$ of the variance of the intensity of internalizing result.
The level of the performance of developmental tasks is significantly associated with a child experiencing severe and accumulated negative life events; the greater the number of such experiences is, the more difficult it is for a child to fulfil social expectations determined for that developmental age. The process of the performance of developmental tasks is supported by the readiness of a child to take advantage of the active strategies of coping with stress. The corrected coefficient of multiple correlation is $R^{2}=.40$, which means that the variable referred to above explains $40 \%$ of the variance of the developmental tasks result.

Life events are also significantly negatively associated with the sense of life satisfaction. The intensity of individual and repeating difficult life experiences is connected with the lowered level of the satisfaction of a child with themselves, with their home, with their life and with their milieu. Individual and repeating negative life events explain $41.10 \%$ of the variance of the sense of life satisfaction result.
Correlation of mental health in middle childhood 
Table 4

Negative life events and the strategies of coping as variables explaining the mental health of children in regression analysis

\begin{tabular}{|c|c|c|c|c|c|}
\hline \multirow[t]{2}{*}{ Age group } & & \multicolumn{2}{|c|}{$\begin{array}{l}\text { Non-standardized } \\
\text { coefficients }\end{array}$} & \multirow{2}{*}{$\begin{array}{c}\begin{array}{c}\text { Standardized } \\
\text { coefficients }\end{array} \\
\beta \\
\end{array}$} & \multirow[t]{2}{*}{$t$} \\
\hline & & $B$ & $S E$ & & \\
\hline \multirow{6}{*}{ Externalizing } & (Constant) & 3.82 & 5.05 & & 0.76 \\
\hline & Individual negative events & 2.50 & 0.55 & .39 & 4.54 \\
\hline & Repeating negative events & 2.13 & 0.57 & .44 & 3.75 \\
\hline & $\begin{array}{c}\text { Predispositional } \\
\text { concentration on emotions }\end{array}$ & 1.64 & 0.87 & .29 & 1.89 \\
\hline & $\begin{array}{l}\text { Situational concentration } \\
\text { on emotions }\end{array}$ & -1.83 & 0.89 & -.31 & -2.05 \\
\hline & \multicolumn{5}{|c|}{$R^{2}=22.20 \%, F(9,172)=6.75, p<.001$} \\
\hline \multirow{4}{*}{ Internalizing } & (Constant) & 10.94 & 4.38 & & 2.50 \\
\hline & Individual negative events & 1.45 & 0.48 & .27 & 3.04 \\
\hline & $\begin{array}{l}\text { Predispositional active } \\
\text { coping }\end{array}$ & -1.49 & 0.79 & -.28 & -1.88 \\
\hline & \multicolumn{5}{|c|}{$R^{2}=23.20 \%, F(9,172)=5.76, p<.001$} \\
\hline \multirow{6}{*}{$\begin{array}{l}\text { Developmental } \\
\text { tasks }\end{array}$} & (Constant) & 19.73 & 0.82 & & 24.05 \\
\hline & Individual negative events & -0.45 & 0.09 & -.38 & -5.03 \\
\hline & Repeating negative events & -0.46 & 0.09 & -.51 & -4.99 \\
\hline & Severity of negative events & 0.06 & 0.02 & -.32 & 2.78 \\
\hline & $\begin{array}{l}\text { Predispositional active } \\
\text { coping }\end{array}$ & 0.36 & 0.15 & .31 & 2.44 \\
\hline & \multicolumn{5}{|c|}{$R^{2}=40.00 \%, F(9,172)=14.41, p<.001$} \\
\hline \multirow{4}{*}{ Life satisfaction } & (Constant) & 29.96 & 1.65 & & 18.19 \\
\hline & Individual negative events & -0.77 & 0.18 & -.32 & -4.27 \\
\hline & Repeating negative events & -0.53 & 0.19 & -.29 & -2.86 \\
\hline & \multicolumn{5}{|c|}{$R^{2}=41.10 \%, F(9,172)=15.02, p<.001$} \\
\hline
\end{tabular}

\section{DISCUSSION}

The connections between mental stress, ways of coping and mental health of individuals have been investigated quite well. However, research is mainly focused on three periods of development: early childhood, adolescence and adulthood. In comparison with the efforts of researchers exploring the periods referred to above, empirical research and, ipso facto, our understanding of the processes occurring in the period of middle childhood are neither so broad nor so profound. That gap in knowledge concerning the development of psychopathological symptoms and the positive aspects of mental health in the period of middle childhood was already apparent in the 1980s (Collins, 1984). In the literature, the necessity of additional research exploring the processes of shaping the paths of development in such an important, and yet underappreciated, period of life, was emphasized. And, although in recent years the percentage of studies conducted in that age group has increased, empirical interests are hardly ever mainly focused on that period of development. Therefore, that conclusion still remains true.

The present research explores the problem of mental health of children in the period of middle childhood. In numerous publications, it is emphasized that, in spite of a certain lack of appreciation of that period of development, it constitutes a very important moment in the life of a young individual. During this period, many significant changes (qualitatively different from the changes during the earlier stages), especially at a cognitive, behavioural and social level, occur. The scope of abstract thinking and 
planning broadens, executive abilities develop, and an ability to control oneself increases, and so does the sense of agency. Developing competencies may, therefore, increase the personal remedial strategies of a child, and, ipso facto, increase the chances of positive adaptation. Changing the developmental environment and commencing school education also contribute to the dramatic development of social contacts. Children's ability to establish interactions with fellow human beings, which is being formed, to form friendships, and also the process of socialization, occurring beyond the structures of the family, are frequently defined as one of the more important developmental tasks of this period. To a large degree, it may also constitute a source of negative life events. In addition, developing motivation and the ability to learn, and also that to acquire knowledge, not only at school, but also for one's own benefit, makes it possible to separate the period of middle childhood from the earlier stages of development. The important conclusion of the literature is that the behaviour and performance of children during their middle childhood can be a predictor of adolescent and adult health status (Collins, 1984).

In the context of the considerations included above, the obtained results of research indicate that there exists a connection between negative life events in the life of a child and disturbances within the scope of their adaptation and good functioning. The results of our research confirm hitherto findings suggesting that all the researched aspects of negative life events are correlated with the aspects of the mental health of children being measured. The obtained results did not confirm the earlier data, in accordance with which accumulated life events are more strongly connected with disorders than individual events are (Garmezy \& Masten, 1994; Masten \& Powell, 2003). In the light of the obtained results, it ought to be concluded that both individual and repeating negative life events are equally important in terms of the occurrence of mental health disorders and the incidence of psychopathological symptoms. In a significant way, the role of the subjective assessment of events being experienced was confirmed. The more youths assess the events occurring in their lives as severe and unpleasant, the more likely it is that there will be disturbances in their development, especially having an externalizing character.

As it had been expected, the study results confirmed a significant association of the active strategies of coping with stress with the positive indicators of mental health in the period of middle childhood. The hitherto conducted research into the consequences of ineffective coping indicates that the influence exerted by those strategies is principally exerted on adjustment and the incidence of psychopathological symptoms (Pincus \& Friedman, 2004). The stress which is being experienced and undertaken remedial activity may modify the psychosocial development, and the state of health, of children and youth (Oginska-Bulik \& Juczyński, 2010). In the present study, the assumption that strategies concentrated upon emotions will constitute an intermediary risk factor in terms of mental health disorders was not confirmed. That may be explained, to a large degree, by the specific character of the situations being the source of stress in children in the period of middle childhood. In this period, the strongest stress is associated with situations connected with the school setting, relationships with peers and contacts with parents (Pincus \& Friedman, 2004). The method applied in the tested model, the purpose of which is conducting the assessment of situational strategies, takes advantage of a story connected with interpersonal relationships, and predispositional strategies are based on an example of a stressful event quoted by a child who is the subject of the research. The domination of the effectiveness of predispositional strategies may result, therefore, from the specific character of the material being tested, because it is possible to conjecture that the story from the past quoted by the studied individuals involved a situation in which they managed to act effectively. In addition, based on research conducted to date, it is very difficult to decide which style of coping applied by children is the most effective with respect to life events of critical importance. The effectiveness of applied strategies is a complex problem, and more and more frequently it is emphasized that it depends not on the selection of a particular strategy, but rather on the availability of those strategies for an individual and the flexibility of the latter in terms of applying the strategies in question. An important role is played by the so-called matching of selected behaviours to the type of an unpleasant event which was experienced by an individual. The difficulties involved in assessing the adaptiveness of the strategies of coping with stress that are applied, and which are discussed in this paper, are made obvious by the results of other research. In the study by Caplan, Bennetto, and Weissberg (1991) it was found, for example, that the application of numerous different strategies results in better psychological adjustment. Furthermore, the effectiveness of strategies depends on the kind of life experience. As reported by Sharrer and Ryan-Wenger (2002), children more frequently applied active strategies in situations connected with school, and emotional strategies in situations connected with medical services (for example, visiting a doctor). Hence, when exploring the issues of the connection between stress and mental health, it would be advisable to take into consideration in further research the diversity of negative life events and the strategies applied to cope with them.

The conclusion from research conducted to date is that, in the case of adults, the ability to cope is more important than stress being experienced. The
Correlation of mental health in middle childhood 
obtained results of research do not confirm that hypothesis as far as children in the period of middle childhood are concerned. In the light of the obtained results of research, it should be acknowledged that the greater predictive power for mental health disorders is that of negative stress events rather than that of remedial strategies. That fact may be explained as caused by the specific character of the functioning of children during this period of development, and especially by emotional dependence on parents, other important adult individuals, and also peers, which still remains substantial.

\section{CONCLUSIONS}

Several elements make the analyses of the mental health of children in the period of middle childhood particularly important. First, the number of children taking advantage of the assistance of psychiatrists and psychologists increases after they turn five (Collins et al., 1984). Second, mental health disorders, and the incidence of psychopathological symptoms, are closely connected with the adjustment of a child to the condition of the school setting and the general educational functioning of that child. And, ultimately, pathological symptoms observed in the period of middle childhood frequently constitute the first sign of serious disorders in the period of adolescence and early adulthood (Compas, Connor-Smith, Saltzman, Harding Thomsen, \& Wadsworth, 2001). Hence, the obtained results of research into the role of negative stress events and remedial strategies for the mental health of children constitute an important element of considerations devoted to adaptation and positive adjustment. The results of previous research have been concentrated, first and foremost, on the negative results of stress, which is viewed as the direct cause of disorders or as a mechanism with an intermediary function in the etiopathogenesis of diseases (Ogińska-Bulik \& Juczyński, 2010). Seen from such a perspective, health is regarded not as a process, but as a state revealing the negative consequences of the impact of negative stress events upon a child. In the context of the present research, it is possible, however, to conclude that it is not only psychopathological symptoms that constitute the negative consequence of stress. Negative stress events are negatively correlated with the positive dimensions of mental health, including the level of the performance of developmental tasks and the sense of life satisfaction in the case of children in the period of middle childhood.

Obviously, the presented study has limitations. First, at certain time points, the numbers of participants in some of the age groups were relatively small. That decreased the power of statistical tests. Consequently, there is an obvious need to replicate the findings with larger data sets. Second, although several different stressors were included, only one person-related variable was used to predict individual variation in stress and coping. Future studies should, therefore, include a variety of individual dispositions, such as temperament, personality variables, motivation, or causal attribution as the predictors of children's stress and coping. Moreover, an important contribution of future research efforts would be the appraisal of different stressful situations according to their controllability, as Gamble (1994) has suggested. In addition, the examination of an interaction between a type of coping style and the type of stressor is warranted. Fourth, future studies should endeavour to combine self-reports and the reports of others to provide valid information on the degree of correspondence between outward behaviours and perceived coping (Anderson \& Jimerson, 2007). Finally, the study focused only on the periods of middle childhood. It would be interesting to examine how those mechanisms continue to play a role in individuals' further development into adolescence and young adulthood.

The issues of stress and remedial strategies applied by children in the period of middle childhood require, therefore, further and insightful explorations. The obtained results of research show the specific character of the developmental period being discussed in this paper. However, there have not been many studies devoted to this area, and there are still numerous questions and doubts concerning the issues of the association between stress and the mental health of children. What requires to be explained, among others, is the significance of the kind of negative experiences (whether those events were of a normative character, or of a non-normative one), the time that has passed since the event (whether similar changes occur immediately after a negative event, or some time later, and, if the latter is the case, how long they persist), and also what the reaction of the immediate milieu of a child to a negative experience was (whether parents were aware of the experience in question, what their reaction was, etc.). I hope that the research results presented here will inspire future studies in the field of prophylactics and promotion of mental health in children in the period of middle childhood.

\section{References}

Anderson, G. E., \& Jimerson, S. R. (2007). Stressful life experiences of children: The correspondence between professional judgments of teachers-in-training and children's perceptions. Psychology in the Schools, 44, 807-821.

Caplan, M., Bennetto, L., \& Weissberg, R. P. (1991). The role of interpersonal context in the assess- 
ment of social problem-solving skills. Journal of Applied Developmental Psychology, 12, 103-114.

Collins, W. A. (1984). Development During Middle Childhood: The Years From Six to Twelve. Washington: NAC.

Compas, B. E., Connor-Smith, J. K., Saltzman, H., Harding Thomsen, A., \& Wadsworth, M. E. (2001). Coping with stress during childhood and adolescence: Problems, progress, and potential in theory and research. Psychological Bulletin, 17, 87-127.

Feinstein, L., \& Bynner, J. (2004). The importance of cognitive development in middle childhood for adulthood socioeconomic status, mental health, and problem behavior. Child Development, 75, 1329-1339.

Gamble, W. C. (1994). Perceptions of controllability and other stressor event characteristics as determinants of coping among young adolescents and young adults. Journal of Youth and Adolescence, $23,65-80$.

Garmezy, N., \& Masten A. S. (1994). Chronic adversities. In: M. Rutter, L. Herzov, \& E. Taylor (eds.), Child and adolescent psychiatry: Modern approaches (pp. 191-208). Oxford: Blackwell Scientific Publication.

Grzegorzewska, I. (2006). Realizacja zadań rozwojowych okresu dorastania przez dzieci leczacych się alkoholików. Niepublikowana praca doktorska [Realization of developmental tasks of adolescence by childrenof recovery alcoholics]. Poznań: UAM.

Grzegorzewska, I. (2013). Odporność psychiczna dzieci alkoholików [The resilience of children from alcoholic families]. Warszawa: Wydawnictwo $\mathrm{Na}-$ ukowe Scholar.

Grzegorzewska, I. (2011). Dorastanie w rodzinach $z$ problemem alkoholowym [Adolescence in families with alcohol problems]. Warszawa: Wydawnictwo Naukowe Scholar.

Juczyński, Z., \& Ogińska-Bulik, N. (2009). Narzędzia pomiaru stresu i radzenia sobie ze stresem [Measurement tools of stress and coping]. Warszawa: PTP.

Lazarus, R. (1999). Hope: An emotion and a vital coping resource against despair. Social Research: An International Quarterly, 66, 653-678.

Lazarus, R., \& Folkman, S. (1984). Stress, appraisal, and coping. New York: Springer Publishing Co.

Lengua, L. J. (2002). The contribution of emotionality and self-regulation to the understanding of children's response to multiple risk. Child Development, 73, 144-161.

Masten, A. S., \& Powell, J. L. (2003). A resilience framework for research, policy, and practice. In: S. S. Luthar (ed.), Resilience and vulnerability: Adaptation in the context of childhood adversities (pp. 1-25). New York: Cambridge University Press.

Melosik, Z. (1999). Ciato i zdrowie w spoteczeństwie konsumpcji [Body and health in society consumption]. Toruń-Poznań: Wydawnictwo Edytor.
Namysłowska, I. (2013). Zdrowie psychiczne dzieci i młodzieży w Polsce - stan rozwoju opieki psychiatrycznej i zadania na przyszłość [Mental health of children and adolescents in Poland - the state of the development of psychiatric care and future goals]. Postępy Nauk Medycznych, 1, 4-9.

Pincus, D., \& Friedman, A. (2004). Improving children's coping with everyday stress: transporting treatment interventions to the school setting. Clinical Child and Family Psychology Review, 7, 223-240.

Ogińska-Bulik, N., \& Juczyński, Z. (2010). Osobowość. Stres a zdrowie [Personality. Stress and Health]. Warszawa: Difin SA.

Radziwiłłowicz, W. (2011). Depresja u dzieci i mtodzieży. Analiza systemu rodzinnego - ujęcie kliniczne [Depression in childhood and adolescence]. Kraków: Wydawnictwo Impuls.

Robins, L., \& Rutter, M. (1990). Straight and devious pathways from childhood to adulthood. Cambridge, UK: Cambridge University Press.

Rolf, J., Masten, A. S., Cicchetti, D., Nuechterlein, K. H., \& Weintraub, S. (1990). Risk and protective factors in the development of psychopathology. Cambridge, UK: Cambridge University Press.

Seligson, J., Huebner, E., \& Valois, R. (2003). Preliminary validation of the Brief Multidimensional Students' Life Satisfaction Scale (BMSLSS). Social Indicators Research, 61, 121-145.

Sęk, H. (1991). Procesy twórczego zmagania się z krytycznymi wydarzeniami życiowymi a zdrowie psychiczne [The processes of creative struggle with critical life events and health mental]. In: H. Sęk (ed.), Twórczość i kompetencje życiowe a zdrowie psychiczne [Creativity and life competence and mental health] (pp. 30-41). Poznań: Wydawnictwo Naukowe UAM.

Sharrer, V., \& Ryan-Wenger, N. (2002). School-age children's self-reported stress symptoms. Pediatrics Nursing, 28, 21-27.

WHO. (2005). Child and adolescent mental health policies and plans. Singapore: World Health Organization.

Wolańczyk, T. (2002). Zaburzenia emocjonalne i behawioralne u dzieci i młodzieży szkolnej w Polsce [Emotional and behavioral disordersin children and adolescents in Poland]. Warszawa: Akademia Medyczna.
Correlation of mental health in middle childhood 